\title{
Kesehatan hidung pada siswa sekolah dasar Kema III Minahasa Utara
}

\author{
${ }^{1}$ Amelia Habibuw \\ ${ }^{2}$ Steward Mengko \\ ${ }^{2}$ Ora I. Palandeng
}

\author{
${ }^{1}$ Kandidat Skripsi Fakultas Kedokteran Universitas Sam Ratulangi Manado \\ ${ }^{2}$ Bagian THT-KL Fakultas Kedokteran Universitas Sam Ratulangi Manado \\ Email: ameliahabibuw09_095@yahoo.com
}

\begin{abstract}
Physiologically, nose has important functions for protecting the body against the disadvantageous condition from our surroundings. This study aimed to obtain the nose health status of students at Sekolah Dasar Inpres Kema III. This was a descriptive study with a cross sectional design. Nose health status was determined by examining the nasal cavity, conchae, mucous layer, secret, septum, and post nasal drip. The results showed that most of the students had normal nose health examination. Conclusion: Most of the students at Sekolah Dasar Inpres Kema III had good nose health status.
\end{abstract}

Keywords: health survey, nose examination

\begin{abstract}
Abstrak: Secara fisiologik hidung mempunyai beberapa fungsi seperti sebagai penyaring dan pertahanan lini pertama dan pelindung tubuh terhadap kondisi lingkungan yang tidak menguntungkan. Penelitian ini bertujuan untuk mengetahui gambaran kesehatan hidung pada siswa Sekolah Dasar Inpres Kema III. Jenis penelitian ialah deskriptif survei desain potong lintang. Gambaran kesehatan hidung setiap responden dilihat dengan memeriksa kavum nasi, konka, mukosa, sekret, septum, dan post nasal drip. Hasil pemeriksaan hidung menunjukan bahwa sebagian besar gambaran kesehatan hidung pada Siswa Sekolah Dasar Inpres Kema III Minahasa Utara normal. Simpulan: Sebagian besar siswa di Sekolah dasar Inpres Kema III Minahasa Utara memiliki status kesehatan hidung yang baik.
\end{abstract}

Kata kunci: survei kesehatan, pemeriksaan hidung

Hidung merupakan salah satu organ penting yang walaupun terlihat kecil namun cukup penting. Secara fisiologis hidung mempunyai beberapa fungsi seperti sebagai penyaring dan pertahanan lini pertama serta pelindung tubuh terhadap kondisi lingkungan yang tidak menguntungkan. ${ }^{1}$

Hidung terletak di pusat sepertiga tengah wajah dan merupakan organ tubuh paling menonjol kedepan dibandingkan dengan organ tubuh yang lain, ${ }^{2}$ namun struktur ini sering diabaikan dalam pembicaraan penyakit manusia. ${ }^{1}$

Hidung terkadang dapat tersumbat oleh karena berbagai penyebab seperti alergi, kelainan anatomi, ataupun massa pada hidung. ${ }^{1}$ Penyakit-penyakit yang dapat timbul di hidung antara lain rhinitis alergi maupun vasomotor, deviasi septum, dan polip hidung. ${ }^{3}$

Bersin, pilek dan hidung gatal atau buntu yang sering terjadi di pagi hari merupakan salah satu gejala rhinitis alergi. Rhinitis alergi merupakan salah satu penyakit alergi yang umumnya diderita pada usia anak sekolah dan dapat terus berlangsung sampai dewasa bila tidak ditangani dengan baik. Angka kejadian rhinis alergi di dunia bervariasi dan dapat mencapai $40 \%$ populasi pada anak dan 
sekitar $10-30 \%$ pada dewasa. ${ }^{4}$

Data dari Departemen Kesehatan Republik Indonesia tahun 2003 menyebutkan bahwa penyakit hidung dan sinus berada pada urutan ke-25 dari 50 pola penyakit peringkat utama atau sekitar 102.817 penderita rawat jalan di rumah sakit terhitung dari anak-anak sampai dewasa. ${ }^{5}$ Anak usia sekolah merupakan generasi penerus bangsa yang akan menjadi tumpuan kualitas bangsa dalam konteks sumber daya manusia yang akan datang. Kelompok usia anak di Indonesia berjumlah sekitar 66 juta atau $28 \%$ dari jumlah penduduk menurut hasil sensus penduduk 2010. ${ }^{4}$

Penelitian ini bertujuan untuk mendapatkan data melalui survei tentang kesehatan hidung pada siswa di Sekolah Dasar Inpres Kema III Minahasa Utara.

\section{METODE PENELITIAN}

Jenis penelitian ini ialah deskriptif survei dengan desain potong lintang. Responden penelitian ialah siswa Sekolah Dasar Inpres Kema III Minahasa Utara yang bersedia mengikuti penelitian yang berlangsung pada tanggal 30 Oktober 2015 di Sekolah Dasar Kema III. Variabel penelitian ialah hasil pemeriksaan hidung pada siswa Sekolah Dasar Inpres Kema III Minahasa Utara yang bersedia mengikuti penelitian dan gangguan hidung yang ditemukan pada saat pemeriksaan.

\section{HASIL PENELITIAN}

Pada Tabel 1 dapat dilihat bahwa jumlah responden yang mengikuti penelitian sebanyak 24 orang, dengan jumlah responden laki-laki $14 \%$ dan responden perempuan $10 \%$.

Tabel 1. Jenis kelamin responden

\begin{tabular}{ccc}
\hline Jenis kelamin & $\mathrm{N}$ & $\%$ \\
\hline Perempuan & 10 & 41,67 \\
Laki-laki & 14 & 58,84 \\
Total & 24 & 100,00 \\
\hline
\end{tabular}

Penelitian dilaksanakan dengan melakukan pemeriksaan langsung pada siswa, dan hasil pemeriksaan diisi pada tabel pemeriksaan THT yang telah disediakan sebelumnya. Tabel pemeriksaan hidung sendiri terdiri atas pemeriksaan kavum nasi, konka, mukosa, sekret, septum dan postnasal drip.

Tabel 2 memperlihatkan hasil pemeriksaan kavum nasi kanan dan kiri. Sebagian besar memperlihatkan hasil lapang. Tidak ditemukan adanya massa baik pada kavum nasi kanan maupun kiri.

Tabel 2. Keadaan kavum nasi

\begin{tabular}{ccccc}
\hline \multirow{2}{*}{ Keadaan } & \multicolumn{2}{c}{$\mathrm{N}$} & \multicolumn{2}{c}{$\%$} \\
\cline { 2 - 5 } & Kiri & Kanan & Kiri & Kanan \\
\hline Lapang & 17 & 17 & 70,83 & 91,43 \\
Massa & 0 & 0 & 0 & 0 \\
Sempit & 7 & 7 & 29,16 & 21,16 \\
Total & 24 & 24 & 100,00 & 100,00 \\
\hline
\end{tabular}

Tabel 3 memperlihatkan pemeriksaan konka kanan dan kiri dengan hasil keseluruhan ialah sebagai berikut: normal pada kanan 6 dan kiri 6 , udim pada kanan 8 dan kiri 8, konka atrofi pada kanan 10 dan kiri 10, sedangkan konka pucat, hipertrofi dan hiperemis tidak ditemukan pada pemeriksaan.

Tabel 3. Keadaan konka

\begin{tabular}{ccccc}
\hline \multirow{2}{*}{ Keadaan } & \multicolumn{2}{c}{$\mathrm{N}$} & \multicolumn{2}{c}{$\%$} \\
\cline { 2 - 5 } & Kiri & Kanan & Kiri & Kanan \\
\hline Normal & 6 & 6 & 25 & 25 \\
Udim & 8 & 8 & 33,33 & 33,33 \\
Udim + & 0 & 0 & 0 & 0 \\
hiperemis & 0 & & & 0 \\
Pucat & 0 & 0 & 0 & 0 \\
Hipertrofi & 0 & 0 & 0 & 41,67 \\
Atrofi & 10 & 10 & 41,67 & 40.00 \\
Total & 24 & 24 & 100.00 & 100.00 \\
\hline
\end{tabular}

Tabel 4 memperlihatkan hasil pemeriksaan mukosa kavum nasi kanan dan kiri. Secara keseluruhan memperlihatkan hasil normal pada kanan berjumlah 8 dan kiri 8 , hiperemis pada kanan berjumlah 6 dan kiri 6, serta livide pada kanan berjumlah 10 dan kiri 10.

Pada Tabel 5 dapat dilihat hasil pemeriksaan sekret dalam kavum nasi. Secara keseluruhan didapatkan keadaan 
normal sebanyak 16 pada kanan dan 16 pada kiri. Sekret serous sebanyak 8 pada kanan dan 8 pada kiri, sedangkan untuk mukoid dan purulen tidak ditemukan.

Tabel 4. Keadaan mukosa

\begin{tabular}{ccccc}
\hline \multirow{2}{*}{ Keadaan } & \multicolumn{2}{c}{$\mathrm{N}$} & \multicolumn{2}{c}{$\%$} \\
\cline { 2 - 5 } & Kiri & Kanan & Kiri & Kanan \\
\hline Normal & 8 & 8 & 33,33 & 33,33 \\
Hiperemis & 6 & 6 & 25 & 25 \\
Livide & 10 & 10 & 41,67 & 41,67 \\
Total & 24 & 24 & 100,00 & 100,00 \\
\hline
\end{tabular}

Tabel 5. Keadaan sekret

\begin{tabular}{ccccc}
\hline \multirow{2}{*}{ Keadaan } & \multicolumn{2}{c}{$\mathrm{N}$} & \multicolumn{2}{c}{$\%$} \\
\cline { 2 - 5 } & Kiri & Kanan & Kiri & Kanan \\
\hline Tidak ada & 16 & 16 & 66,67 & 66,67 \\
Serous & 8 & 8 & 33,33 & 33,33 \\
Mukoid & 0 & 0 & 0 & 0 \\
Purulen & 0 & 0 & 0 & 0 \\
Total & 24 & 24 & 100,00 & 100,00 \\
\hline
\end{tabular}

Dari hasil pemeriksaan septum kanan dan kiri (Tabel 6) dapat dilihat keadaan septum yang normal kiri dan kanan sebesar $100 \%$ yaitu seluruh responden.

Tabel 6. Keadaan septum

\begin{tabular}{ccccc}
\hline \multirow{2}{*}{ Keadaan } & \multicolumn{2}{c}{$\mathrm{N}$} & \multicolumn{2}{c}{$\%$} \\
\cline { 2 - 5 } & Kiri & Kanan & Kiri & Kanan \\
\hline Normal & 24 & 24 & 0 & 0 \\
Deviasi & 0 & 0 & 0 & 0 \\
Abses & 0 & 0 & 0 & 0 \\
Hematoma & 0 & 0 & 0 & 0 \\
Total & 24 & 24 & 100,00 & 100,00 \\
\hline
\end{tabular}

Berdasarkan Tabel 7 tidak ditemukan adanya post nasal drip pada saat penelitian.

Tabel 7. Post nasal drip

\begin{tabular}{ccccc}
\hline \multirow{2}{*}{ Keadaan } & \multicolumn{2}{c}{$\mathrm{N}$} & \multicolumn{2}{c}{$\%$} \\
\cline { 2 - 5 } & Kiri & Kanan & Kiri & Kanan \\
\hline Tidak & & 24 & & \\
ada & 24 & & 100,0 & 100,0 \\
Ada & 0 & 0 & 0,0 & 0,0 \\
Total & 24 & 24 & 100,0 & 100,0 \\
\hline
\end{tabular}

\section{BAHASAN}

Penelitian survei kesehatan hidung ini dilakukan pada siswa Sekolah Dasar Kema III Minahasa Utara dengan desain potong lintang. Penelitian ini diikuti oleh 24 orang yang bersedia menjadi responden penelitian dengan persentase perempuan $(41,67 \%)$ lebih tinggi dari laki-laki (58,34\%). Pada penelitian ini terlihat sebagian besar memperlihatkan hasil normal.

Pemeriksaan kavum nasi kanan dan kiri pada responden perempuan dengan adanya lapang pada kavum nasi adalah 6 orang. Pada laki-laki dengan adanya lapang pada kavum nasi adalah 11 orang, sempit pada kavum nasi adalah 2 orang sedangkan pada laki-laki 5 orang.

Pada penelitian sebelumnya yang dilakukan oleh Imawo et al. ${ }^{6}$ terhadap anakanak Pasar Bersehati Komunitas Dinding Manado sebanyak 32 anak, didapatkan hasil normal pada semua sampel 32 anak $(100,00 \%)$ baik perempuan maupun lakilaki.

Gangguan yang dapat terjadi pada kavum nasi salah satunya ialah polip hidung. Polip hidung ialah massa lunak yang mengandung banyak cairan di dalam rongga hidung, berwarna putih keabuabuan, yang terjadi akibat inflamasi mukosa. ${ }^{7}$ Di Amerika Serikat, insiden polip nasi pada anak adalah $0,1 \%$, namun insiden ini meningkat pada anak-anak dengan fibrosis kistik yaitu $6-48 \%{ }^{8}$

Pada pemeriksaan konka kanan dan kiri, responden perempuan dengan konka udim sebanyak 2 orang dan laki-laki 6 orang. Responden laki-laki dengan konka atrofi sebanyak 10 orang pada sedangkan perempuan tidak ditemukan; dan 6 orang lainnya normal.

Pada penelitian yang dilakukan Imawo et al. ${ }^{6}$ terhadap anak-anak Pasar Bersehati Komunitas Dinding Manado sebanyak 32 anak didapatkan hasil terbanyak yaitu normal 28 anak $(87,5 \%)$ pada konka kiri dan pada konka kanan 30 anak $(93,8 \%)$. Kelainan berupa udem ditemukan pada 2 anak $(6,3 \%)$ pada konka kanan, dan hiperemis 2 anak $(6,3 \%)$ pada konka kanan dan 2 anak $(6,3 \%)$ pada konka kiri.

Salah satu kelaianan pada konka ialah atrofi misalnya pada rhinitis atrofi. Rhinitis 
atrofi merupakan infeksi hidung kronik, yang ditandai adanya atrofi progresif pada mukosa dan tulang konka dan pembentukan krusta. Secara klinis, mukosa hidung menghasilkan sekret yang kental dan cepat mengering, sehingga berbentuk krusta yang berbau busuk. Penyakit ini lebih banyak menyerang perempuan daripada laki-laki, terutama pada usia pubertas. ${ }^{9,10}$ Pemeriksaan penunjang untuk membantu menegakkan diagnosis ialah transiluminasi, foto rontgen, foto sinus paranasalis, pemeriksaan mikroorganisme, uji resistensi kuman, pemeriksaan darah tepi, pemeriksaan Fe serum, pemeriksaan histopatologik, dan pemeriksaan serologik darah. ${ }^{9}$ Pengobatan medis terbaik untuk rhinitis atrofi sampai saat ini hanya bersifat paliatif termasuk dengan irigasi dan membersihkan krusta yang terbentuk, terapi sistemik dan lokal dengan endokrin, steroid, antibiotic, vasodilator, pemakaian iritan jaringan lokal ringan seperti alcohol, dan salep pelumas. Penekanan terapi utama ialah pembedahan, yaitu usaha-usaha langsung mengecilkan rongga hidung, dan juga memperbaiki pasokan darah mukosa hidung. Tujuan pengobatan ialah menghilangkan faktor etiologi dan menghilangkan gejala. Pengobatan dapat diberikan secara konservatif, jika tidak tertolong dengan operasi. $^{10}$

Pemeriksaan mukosa kanan dan kiri, pada responden perempuan ditemukan mukosa dengan hiperemis sebanyak 2 orang, mukosa dengan livide 3 orang dan 5 orang lainnya normal. Pada responden lakilaki, mukosa dengan livide sebanyak 5 orang, mukosa hiperemis 4 orang, dan lainnya normal.

Penelitian Iwawo et al. ${ }^{6}$ pada anakanak Bersehati Komunitas Dinding Manado yang diikuti oleh 32 anak, diperoleh hasil terbanyak yaitu normal baik mukosa kanan dan mukosa kiri adalah 30 anak $(93,8 \%)$, kelainan hiperemis 2 anak (6,3\%) pada mukosa kanan dan 2 anak $(6,3 \%)$ pada mukosa kiri. Kelainan yang dapat terjadi pada mukosa, contohnya rinitis alergi. Rinitis alergi merupakan suatu penyakit inflamasi yang diawali dengan tahap provokasi/reaksi alergi. ${ }^{11}$ Pada pemeriksaan rinoskopi anterior mukosa hidung pada pasien alergi biasanya basah, pucat dan berwarna merah jambu keabuan disertai adanya sekret encer yang banyak. Bila gejala persisten, mukosa inferior tampak hipertrofi. ${ }^{12}$

Pemeriksaan sekret hidung pada responden perempuan dengan serous sebanyak 6 orang dan lainnya tidak ditemukan, sedangkan pada responden lakilaki dengan serous sebanyak 2 orang dan lainnya tidak ditemukan. Pada penelitian Iwawo et al. ${ }^{6}$ pada anak-anak Bersehati Komunitas Dinding Manado diperoleh hasil terbanyak tidak ada sekret sebanyak 27 anak $(84,4 \%)$ pada hidung kanan dan 28 anak $(87,5 \%)$ pada hidung kiri. Didapatkan juga sekret serous 2 anak (6,3\%) pada hidung kanan dan 1 anak $(3,1 \%)$ pada hidung kiri, sedangkan untuk sekret mukoid yaitu 3 anak $(9,4 \%)$ baik hidung kanan maupun hidung kiri.

Sekret serous merupakan sekret hidung encer yang sering ditemukan pada pasien dengan rhinitis alergi dan rinitis vasomotor. Jenis sekret ini terdiri atas protein pembuluh darah yang bocor dari pembuluh darah yang permeabel dan sering terjadi pada kasus alergi. Sekret purulen (nanah) merupakan sekret yang bersifat kental, putih kekuningan dan kadang berbau busuk. Sekret purulen sering ditemukan pada penderita sinusitis yaitu inflamasi mukosa sinus paranasal dengan penyebab utamanya infeksi virus yang selanjutnya dapat diikuti oleh infeksi bakteri. ${ }^{13}$

Pada pemeriksaan septum kanan dan kiri, seluruh responden baik perempuan maupun laki-laki. Pada penelitian Iwawo et al. ${ }^{6}$ pada anak-anak Bersehati Komunitas Dinding Manado tidak ditemukan kelainan pada semua anak $(100,0 \%)$ baik hidung kanan maupun kiri.

Post nasal drip adalah akumulasi lendir di belakang hidung dan tenggorokan yang menjurus pada atau memberikan sensasi dari tetesan lendir yang menurun dari belakang hidung. Keadaan ini sering terjadi pada pasien rhinosinusitis yaitu penyakit inflamasi mukosa yang melapisi hidung 
dan sinus paranasal. Peradangan ini sering bermula dari infeksi virus pada selesma, yang kemudian karena keadaan tertentu berkembang menjadi infeksi bakterial dengan penyebab bakteri patogen yang terdapat di saluran nafas bagian atas. ${ }^{14}$

Rinoskopi anterior merupakan pemeriksaan rutin untuk melihat tanda patognomonik yaitu sekret purulen di meatus medius atau superior, atau pada rinoskopi posterior tampak adanya sekret purulen di nasofaring (post nasal drip). ${ }^{15}$

\section{SIMPULAN}

Berdasarkan hasil penelitian yang dilakukan pada siswa di Sekolah Dasar Inpres Kema III Minahasa Utara dapat disimpulkan bahwa siswa-siswa tersebut memiliki kesehatan hidung yang baik.

\section{SARAN}

Perlu dilakukan penelitian lebih lanjut, agar dapat mendeteksi gangguan hidung serta dapat membantu didalam pencegahan lebih dini.

Sebaiknya untuk penderita dengan gangguan hidung yang lebih berat, perlu dilakukan pemeriksaan lebih lanjut pada bagian THT-KL dan dikonsultasikan ke dokter spesialis THT agar segera mendapatkan penanganan dan pengobatan yang lebih memadai.

\section{DAFTAR PUSTAKA}

1. Hilger PA. Hidung: Anatomi dan fisiologi terapan. In: Adams GL, Boies LR, Higler PA, editors. Boeis Buku Ajar Penyakit THT (6th ed). Jakarta: EGC, 1997; p. 173, 200.

2. Snell RS. Anatomi Klinik untuk Mahasiswa Kedokteran (6th ed). Jakarta: EGC, 2006; p. 803.

3. Soetjipto D, Mangunkusumo E, Wardani R. Sumbatan hidung. In: Soepardi E, Iskanar N, Bashirudin J, Restuti R, editors. Buku Ajar Ilmu Kesehatan Telinga Hidung Tenggorok (7th ed). Jakarta: FKUI, 2012; p. 96.

4. Depkes RI. Anak usia sekolah menjadi tumpuan kualitas bangsa. 2014. [cited 20 September 2015]. Available from: www.gizikia.depkes.go.id/sekretariat/a nak-usia-sekolah-menjadi-tumpuan kualitas-bangsa/

5. HTA Indonesia. Functional endoscopic sinus surgery di Indonesia (homepage on the internet). 2006. [cited 10 Desember 2015]. Available from: http: //buk. depkes.go.id/index.php

6. Iwawo I, Mengko S, Dehoop J. Survei kesehatan hidung anak pasar Bersehati Komunitas Dinding Manado [Skripsi]. Manado: Fakultas Kedokteran Universitas Sam Ratulangi; 2015.

7. Mangunkusumo E, Wardani R. Polip hidung. In: Soepardi E, Iskanar N, Bashirudin J, Restuti R, editors. Buku Ajar Ilmu Kesehatan Telinga Hidung Tenggorok (7th ed). Jakarta: FKUI, 2012; p. 101-03.

8. Asnir AR. Rinitis atrofi. 2004 [cited 1 Desember 2015]. Available from: http://www.kalbe.co.id.

9. Endang M, Nusjirwan R. Rinorea, infeksi hidung dan sinus. Buku Ajar Ilmu Kesehatan Telinga, Hidung, Tenggorok, Kepala \& Leher (5th ed). Jakarta: Fakultas Kedokteran Universitas Indonesia, 2006.

10. Al-Faith M. Rinitis Atrofi. 2007. [cited 1 Desember 2015]. Available from: http://hennykartika.wordpress.com.

11. Irawati N, Kasakeyan E, Rusmono N. Rinitis Alergi. In: Soepardi E, Iskanar $\mathrm{N}$, Bashirudin J, Restuti R, editors. Buku Ajar Ilmu Kesehatan Telinga Hidung Tenggorok (7th ed). Jakarta: FKUI, 2012; p. 106.

12. Nguyen QA. Allergic rhinitis. 2015. [cited 1 Desember 2015]. Available from: http://emedicine.medscape.com/article/ 834281-overview

13. Suryadi ME. Sinusitis. 2014. [cited 1 Desember 2015]. Available from: http://repository.usu.ac.id/bitstream/123 456789/39684/4/Chapter\%20II.pdf

14. Pratter MR. Chronic upper airway cough syndrome secondary to rhinosinus diseases. 2006 [cited 10 Desember 2015]. Available from: http:// chestjournal.chestpubs.org/content/129/ 1_suppl/63S.full.html

15. Soepardi EA. Pemeriksaan THT-KL. Soepardi E, Iskanar N, Bashirudin J, Restuti R, editors. Buku Ajar Ilmu Kesehatan Telinga Hidung Tenggorok (7th ed). Jakarta: FKUI, 2012; p. 4. 